\title{
The climate-smart village approach: framework of an integrative strategy for scaling up adaptation options in agriculture
}

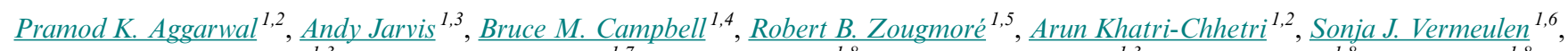 \\ Ana Maria Loboguerrero $^{1,3}, \underline{\text { Leocadio S. Sebastian }}^{1,7}$, James Kinyangi $^{1,8}, \underline{\text { Osana Bonilla-Findji }}^{1,3}$, Maren Radenv $^{1,8}, \underline{\text { John Recha }}^{1,8}$, \\ Deissy Martinez-Baron $^{1,3}, \underline{\text { Julian Ramirez-Villegas }}^{3}$, Sophia Huyer ${ }^{1,9}, \underline{\text { Philip Thornton }}^{1,8}, \underline{\text { Eva Wollenberg }}^{1,10}$, James Hansen $^{1,11}$,

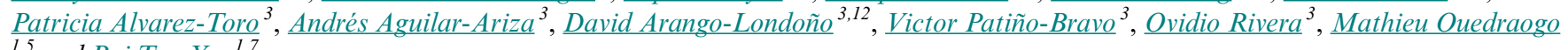 \\ ${ }^{1,5}$ and Bui Tan Yen ${ }^{1,7}$
}

\begin{abstract}
Increasing weather risks threaten agricultural production systems and food security across the world. Maintaining agricultural growth while minimizing climate shocks is crucial to building a resilient food production system and meeting developmental goals in vulnerable countries. Experts have proposed several technological, institutional, and policy interventions to help farmers adapt to current and future weather variability and to mitigate greenhouse gas (GHG) emissions. This paper presents the climate-smart village (CSV) approach as a means of performing agricultural research for development that robustly tests technological and institutional options for dealing with climatic variability and climate change in agriculture using participatory methods. It aims to scale up and scale out the appropriate options and draw out lessons for policy makers from local to global levels. The approach incorporates evaluation of climate-smart technologies, practices, services, and processes relevant to local climatic risk management and identifies opportunities for maximizing adaptation gains from synergies across different interventions and recognizing potential maladaptation and trade-offs. It ensures that these are aligned with local knowledge and link into development plans. This paper describes early results in Asia, Africa, and Latin America to illustrate different examples of the CSV approach in diverse agroecological settings. Results from initial studies indicate that the CSV approach has a high potential for scaling out promising climate-smart agricultural technologies, practices, and services. Climate analog studies indicate that the lessons learned at the CSV sites would be relevant to adaptation planning in a large part of global agricultural land even under scenarios of climate change. Key barriers and opportunities for further work are also discussed.
\end{abstract}

Key Words: adaptation; climate change; climate-smart agriculture; climate-smart villages; resilience; scaling out

\section{INTRODUCTION}

Although global food production has increased in the past few decades, almost 800 million people still have insufficient food, especially in South and Southeast Asia, the Caribbean, and SubSaharan Africa (Food and Agriculture Organization (FAO) 2015). Moreover, global food production must double by 2050 to match population and income growth (Alexandratos and Bruinsma 2012), and much of this must happen in Asia and Africa. These regions are characterized by high population growth, widespread poverty, and low agricultural productivity. Climate change exacerbates the problem.

Agricultural production systems across the world are expected to change in response to climate change, posing major challenges to the livelihoods and food security of millions of people (Intergovernmental Panel on Climate Change (IPCC) 2014). Food production will be impacted due to increased temperatures, changed rainfall patterns, and more frequent and intense floods and droughts (Lobell et al. 2012, Schellnhuber et al. 2013, Rosenzweig et al. 2014). The impacts of climate change on crop yields indicate that yield losses may be up to $60 \%$, depending on crop, location, and future climate scenario (Challinor et al. 2014, Rosenzweig et al. 2014, Asseng et al. 2015). Increasing climatic variability may further complicate agricultural production and food security as recent studies have shown that almost one-third of yield variability is related to climatic variability (Ray et al. 2015). Agricultural food systems, contributing 19-29\% of global greenhouse gas (GHG) emissions (Vermeulen et al. 2012), are not only vulnerable to global climate change but also the second largest contributor to its causes.

There are many options to reduce the negative impacts of climate change on agricultural systems, make them resilient to climate change, and reduce emissions. In some cases, climate change may even be beneficial. Options range from change in crop management, such as sowing time, to change in cropping systems

\footnotetext{
${ }^{1}$ CGIAR Research Program on Climate Change Agriculture and Food Security (CCAFS), ${ }^{2}$ Borlaug Institute for South Asia (BISA) and International Maize and Wheat Improvement Center (CIMMYT), New Delhi, India, ${ }^{3}$ International Center for Tropical Agriculture (CIAT), Cali, Colombia, ${ }^{4}$ International Center for Tropical Agriculture (CIAT), c/o University of Copenhagen, ${ }^{5}$ International Crops Research Institute for the Semi-Arid Tropics (ICRISAT), Bamako, Mali, ${ }^{6} \mathrm{Hoffmann}$ Centre on Sustainable Resource Economy, London, UK, ${ }^{7}$ International Rice Research Institute (IRRI), Hanoi, Vietnam, ${ }^{8}$ International Livestock Research Institute (ILRI), Nairobi, Kenya, ${ }^{9}$ Women in Global Science and Technology (WISAT), Brighton, Ontario, Canada, ${ }^{10}$ University of Vermont (UVM), Burlington, Vermont, USA, ${ }^{11}$ International Research Institute for Climate and Society (IRI), Columbia University, New York, New York, USA, ${ }^{12}$ Pontificia Universidad Javeriana, Department of Natural Sciences and Mathematics, Cali, Colombia
} 
and land use to adjust to new climates (Porter et al. 2014). Many technologies and practices can increase crop yields, farm income, and input-use efficiency, and may reduce GHG emissions (KhatriChhetri et al. 2017).

Climate-smart agriculture (CSA) aims to increase sustainable agricultural production by adapting to and building resilience to climate change. It focuses on food security and national development goals and, where possible, it also aims to reduce or remove GHG emissions (Lipper et al. 2014, Steenwerth et al. 2014). Recent analyses indicate that although several CSA programs and on-farm studies were successful, there is only weak uptake of many innovative CSA practices and technologies (Campbell et al. 2014, Westermann et al. 2015). For example, new water management practices and technologies in India were adopted by only $12 \%$ of farmers in the last 40 years (Palanisami et al. 2015). Similarly, adoption of mitigation options in agriculture is very low in the developing countries (Thornton and Herrero 2010).

One factor that contributes to low uptake of new technologies is that development practitioners lack evidence of how the innovations can be practically incorporated into agricultural systems. They need to know how farmers can achieve synergies and minimize trade-offs in implementing multiple interventions on real farms. Climate change complicates this because its impacts will vary across locations. Effective implementation therefore requires an integrated approach in which science, technology, and decision making interact with local socioeconomic conditions and cultures (Steenwerth et al. 2014).

To generate the evidence on the efficacy of climate-smart options, the Consultative Group for International Agricultural Research (CGIAR) research program on Climate Change, Agriculture and Food Security (CCAFS) is implementing a climate-smart village (CSV) approach in Asia, Africa, and Latin America (Aggarwal et al. 2013). This paper describes the conceptual framework of the CSV approach and the ongoing processes involved in designing and implementing them. The CSV approach is a key part of the agriculture research-for-development (AR4D) agenda to address climate change challenges for food security (Campbell et al. 2016). We illustrate different examples of the CSV approach across a range of vulnerable agroclimatic regions and discuss some emerging lessons learnt.

\section{THE CLIMATE-SMART VILLAGE APPROACH}

The CSV approach is an AR4D approach to test, through participatory methods, technological and institutional options for dealing with climate change in agriculture. It aims to generate evidence at local scales of what climate-smart agricultural options work best, where, why, and how, and use this evidence to draw out lessons for policy makers, agricultural development practitioners, and investors from local to global levels. The testing is done through a multistakeholder collaborative platform at CSV sites. The sites are a cluster of villages, small landscapes, or 10 $\mathrm{km}^{2}$ grids. Every CSV site has its own theory of change (ToC; a narrative description of the logical causal chain from research activities to impact) linked to national priorities to ensure that it is consistent with initiatives and actions across different scales. The process builds on Lipper et al.'s (2014) theory of climatesmart agriculture (CSA).
The strategy of the CSV approach is to:

1. Understand the effectiveness of a variety of CSA options (practices, technologies, services, programs, and policies) not only to enhance productivity and raise incomes, but also to build climate resilience, increase adaptive capacity, and wherever possible, reduce GHG emissions;

2. Develop (no regrets) solutions in anticipation of future climate change impacts;

3. Understand the socioeconomic, gender, and biophysical constraints and enablers for adoption; and

4. Test and identify successful adoption incentives, finance opportunities, institutional arrangements, and scaling out/ up mechanisms while ensuring alignment with local and national knowledge, institutions, and development plans.

Figure 1 illustrates the major components of a typical CSV approach. Climate-smart agriculture interventions are considered in a broad sense by including practices, technologies, climate information services, insurance, institutions, policies, and finance. There is no fixed package of interventions or a one-size-fits-all approach. Options differ based on the CSV site, its agroecological characteristics, level of development, and capacity and interest of the farmers and of the local government. The results of the CSV approach are usually a portfolio of CSA options and institutional and financial mechanisms that enable their successful adoption. Promising innovations are then available to be scaled out by the national/subnational governments, nongovernmental organizations (NGOs), and private-sector actors in regions with similar agroecological conditions.

Fig. 1. Key components of a CSV AR4D approach.

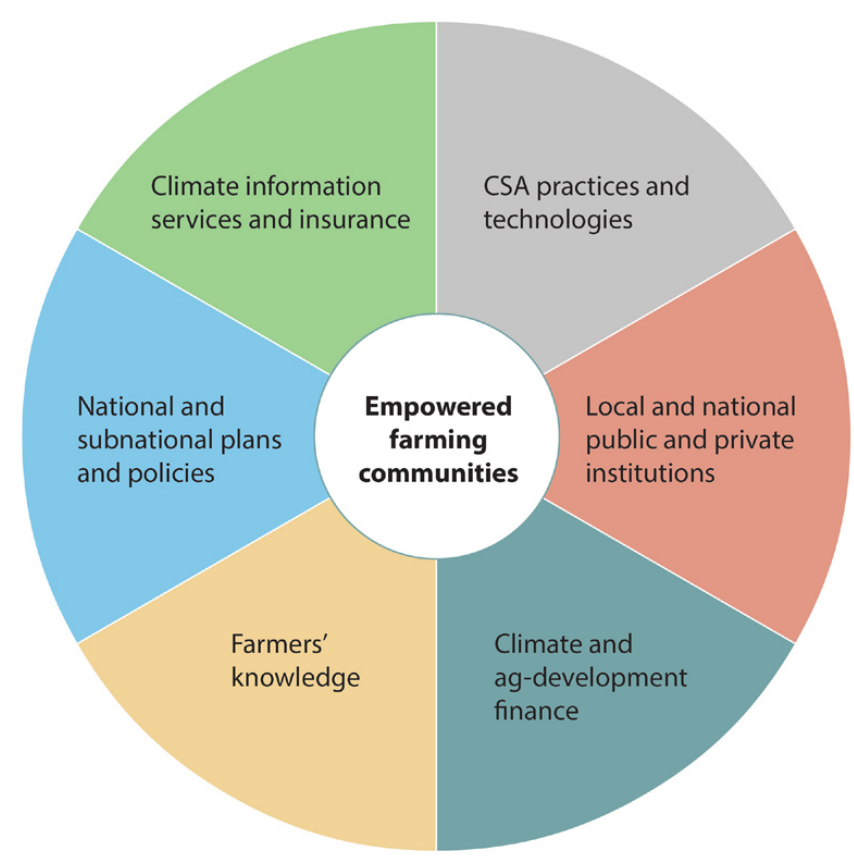


Fig. 2. Outline of the steps in a typical CSV AR4D site. Steps are based on stakeholder engagement and seldom follow a simple linear model.

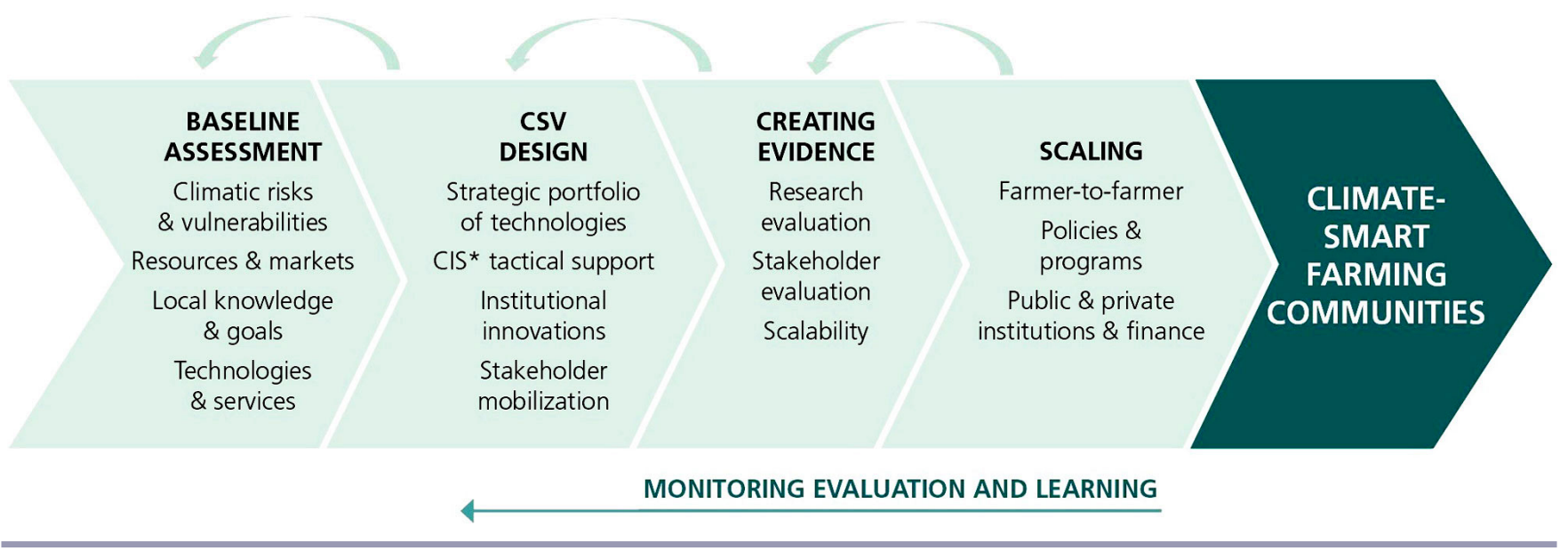

An ideal CSV approach provides five types of decision support to farmers and other stakeholders:

1. Village/community agricultural land use plans and contingency plans considering current and future climate risks, agroecological and socieconomic conditions, and markets.

2. Portfolios of agricultural practices, technologies, and programs that do not become maladaptive in future climate and market scenarios are assessed using models.

3. Strategic guidance before (where feasible based on seasonal forecasts) and during the planting season on the most suitable CSA practices, technologies, services, processes, and institutional options considering market and resource availability such as capital, labor, and markets. This is done in a participatory mode with local farmer groups such as farmers' self-help groups, water-users associations, local extensions systems, or local private-sector actors.

4. Tactical guidance to farmers on using real-time weather forecasts and value-added information and communication technology (ICT)-based agroadvisories; on accessing good quality inputs and technologies for improving water/ nutrient/energy use efficiencies, and on risk transfer through insurance mechanisms in case of crop and livestock losses.

5. Policy-level guidance on barriers and options to unlock CSA with local and national development, including consideration of financial needs to drive scaling.

The CSV approach differs from existing agricultural development approaches, which usually depend on substantial external funding. When the funding ceases, the project unravels (Millennium Villages Project 2016). In contrast, the key focus in a typical CSV is on strengthening capacities and empowering the farming communities and their local organizations. In the process, partners in the CSV approach commit only limited resource support to catalyze the process.

\section{METHODS}

Key steps of the climate-smart village approach implementation The CSV approach, which consists of four steps, guides adaptation planning and on-the-ground implementation with the objective of transforming farming communities to be more climate smart (Fig. 2). Figure 2 outlines the steps in a typical CSV AR4D site. Implementation of these steps is based on stakeholder engagement and seldom follows a simple linear model.

Baseline assessment: Implementation of the CSV approach begins by assessing climate-related risks and vulnerabilities to agriculture at the household/village/landscape level. Historical climate data are analyzed to assess risks such as the probability of sowing failure due to inadequate rainfall at the start of the season. It also includes risks of wet and dry spells, and periods of heat or cold stresses during the cropping season. Future climate scenarios are analyzed to assess the likely change in risk profiles and long-term suitability of the main cropping and livestock systems. Secondary data are used to assess GHG emissions from agriculture and simple calculators in those regions where mitigation is relevant.

Baseline assessment includes the natural (land, water, and soil) and physical (infrastructure such as irrigation, technology, and markets) resources available. It also includes assessment of socioeconomic resources such as human (labor and education), financial (source and amount of revenue and budget), and social (institutions and networks) resources. Local communities help guide the CSV design process, which includes their knowledge of climatic risk management.

A quick participatory assessment is made of the various practices and technologies being used in the village/region, as well as the potential ones that can be adopted, guided by agronomic studies in the region or homologous regions elsewhere. Availability of climate information services - such as weather-based agroadvisories and agriculture insurance schemes in the region - is also assessed.

Successful implementation of the CSV approach also hinges on strong institutions and enabling policies that can support adaptation activities at the village level. Assessment of current 
Fig. 3. Types of climate-smart options that may be tested as part of context specific portfolios in the CSV sites.

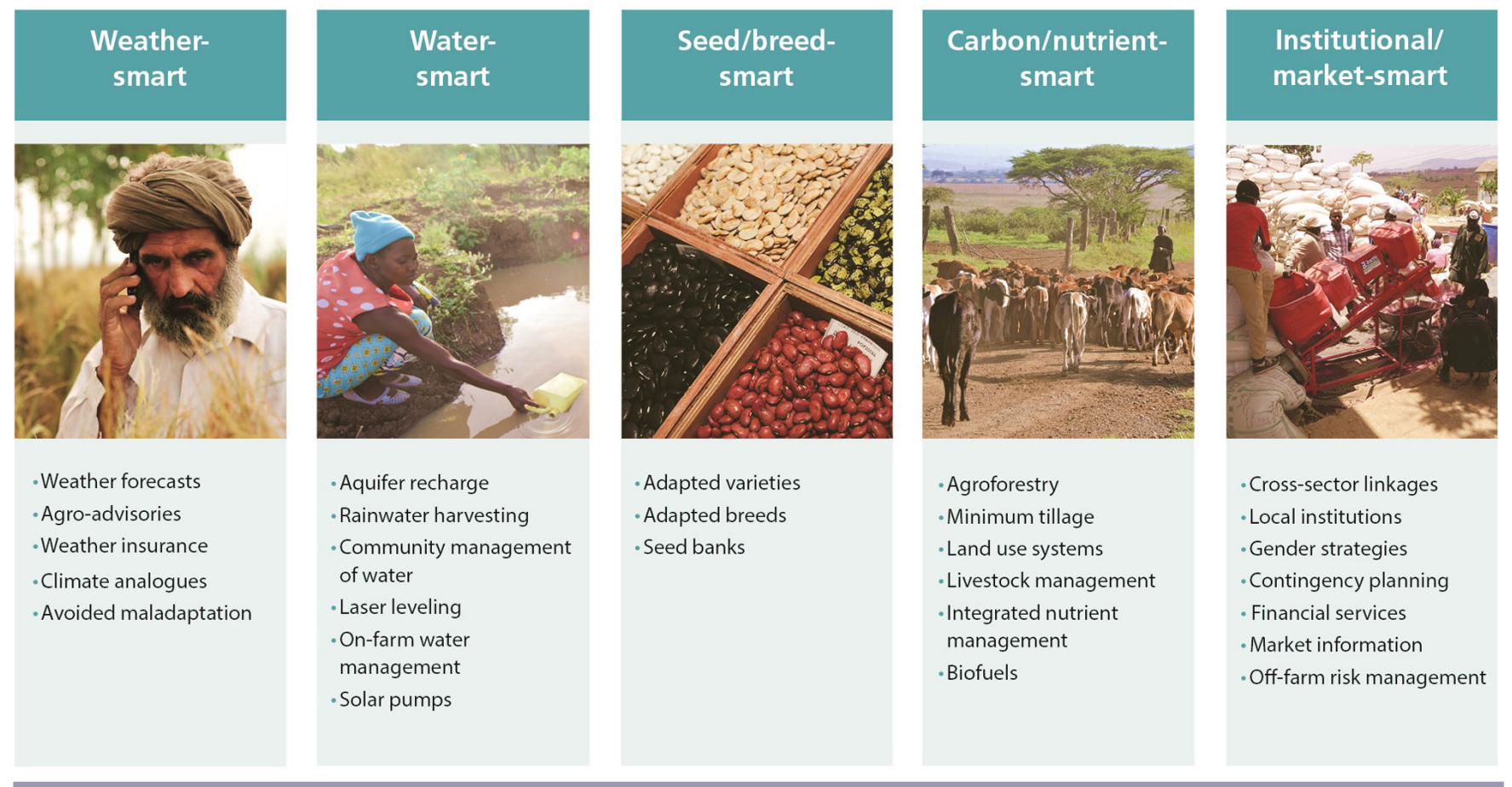

adaptation policies and institutions at different scales is essential to identify the potential for cooperation with and leveraging support from other entities. These assessments indicate the scope for mainstreaming the CSV approach into local adaptation policies and plans including other development initiatives. An evaluation is also done by gender and age to understand the different perspectives, division of labor, decision-making patterns, opportunities, and capacities in households and communities (Quisumbung and Pandolfelli 2010, Doss and Kieran 2013, Perez et al. 2015).

CSV design: This step primarily focuses on developing a portfolio of practices and technologies dealing with food security, adaptation, and mitigation and on climate-information services that need to be initially piloted in the CSVs. The portfolio includes the following (Fig. 3):

- Weather-smart activities (weather forecasts, climateinformed agroadvisories, weather insurance, climate analogs as a tool for forward planning, strategies to avoid maladaptation)

- Water-smart practices (aquifer recharge, rainwater harvesting, community management of water, laser-land leveling, microirrigation, raised-bed planting, solar pumps)

- Seed/breed smart (adapted varieties and breeds, seed banks, including community-based activities)

- Carbon/nutrient-smart practices (agroforestry, minimum tillage, land use systems, livestock management, integrated nutrient management, biofuels), and

- Institutional/market smart activities (crosssectoral links; local institutions, including learning platforms or farmer- to-farmer learning and capacity development, contingency planning, financial services, market information, genderequitable approaches, and off-farm risk management strategies)

Strategic decision making in the CSV approach is a participatory activity. Proposed interventions must be relevant to the conditions defined by the baseline and show promise for wider scale relevancy beyond the CSV. The CSA practices, technologies, and services included in the portfolio for any site are the outcome of group discussions with women and men farmers, local government officials and researchers. Various tools - such as choice experiments, indicators-based ranking methods, and simple stakeholders' prioritization - are used for this exercise. The CSA portfolio may be influenced by gender difference in awareness levels, as well as by the choice of CSA technologies by the stakeholders. Several CCAFS projects have published details of how CSV portfolios of climate-smart interventions have been selected and designed (Taneja et al. 2014, Corner-Dolloff et al. 2015).

Creating evidence: Once a portfolio has been designed, field evidence for this is developed in a two-step process. First, a narrow range of interventions/portfolios is evaluated in a multistakeholder research platform (including CGIAR, national agricultural research systems, NGOs, and private-sector players, farmers and their institutions) established in CSV sites. The process assesses the benefits, synergies, and trade-offs of the technologies from the perspective of individual farmers (men, women, and youth) as well as of the aggregate community/landscape by using wellestablished principles of on-farm and farmers field research. Detailed evaluation is conducted using surveys, farmer group evaluations, and ICT-based feedback tools. Modeling is often 
used to supplement the results of on-farm evaluation, especially to estimate the benefits of resilience and mitigation benefits through time. In the second step, the final portfolios are evaluated by farmers on a larger scale. Crowdsourcing of experiences is used in order to understand farmers' preferences and technology adaptation domains across CSV sites in the region. Due consideration is also given on the identification and evaluation of constraints and barriers to adoptions of interventions along with ways to overcome them.

Scaling up and scaling out: Once intervention portfolios are successfully demonstrated, the evidence generated in the CSVs is used to contribute to scaling up and out promising innovations. Scaling mechanisms tested across the regions include:

- Horizontal scaling (scaling out) of climate-smart options: CSVs provide demonstration sites for farmer-to-farmer learning (often through self-help groups or producer organizations) and/or enable local promotion of CSA options through local government plans, programs, and policies or through private-sector business models.

- Vertical scaling (scaling up): CSV research and lessons learned provide evidence for the efficacy of practices, technologies, services, processes, and institutional options and are thus able to: influence large-scale CSA investment plans; promote mainstreaming of institutional changes; and/or inform policy instruments.

Horizontal scaling out is done from farmer to farmer through networking using ICT-based tools, farmers' fairs, farmer exchange visits, and participatory videos of the adopted technologies, or through engagement with local government institutions. Connecting with women's organizations is another effective scaling-out approach. Institutional and financial needs are determined, for both local and national (or subnational) contexts, often using appropriate business models. The potential for consolidation and convergence of current agricultural development schemes/plans in the region is explored. For instance, national programs/schemes on water management, alternative energy, agricultural extension, and subsidies in agricultural inputs such as farm machinery, seeds, and fertilizers can have added value to leverage resources and investments from different sources into adaptation and mitigation goals, and minimize transaction costs and maximize synergies in CSVs. Consideration of national and regional gender machineries and social development programs also helps to integrate social inclusion concerns into the CSVs as well as to orient social development programs to climate change impacts and action.

Monitoring and evaluation provide feedback to the CSV design process, which is based on learning and adjustment. Finally, adaptation pathways for the CSA approach-including technology and services portfolios, capacity building programs, institutional and financial mechanisms, and potential costs and benefits of program implementation - are presented to policy makers for scaling up through replication in other sites, or provision of incentives for adoption through large-scale agricultural investment plans. Although conceptually this step is placed at the end of the sequence (Fig. 2), it can vary according to the CSV context. Individuals and institutions with policy reach are often engaged early in the process, sometimes even in the baseline assessment stage, which helps to build trust, interest, and common purpose. But it can also lead to "messy" processes, where external agencies may wish to promote scaling-out processes prematurely, even while baseline evidence is being collected.

\section{RESULTS}

\section{Distribution of climate-smart villages and their climate representativeness}

The CCAFS started piloting the CSV AR4D approach in 2012 in Africa (Burkina Faso, Ghana, Mali, Niger, Senegal, Kenya, Ethiopia, Tanzania, and Uganda) and South Asia (Bangladesh, India, and Nepal). In 2014, more projects were established in Latin America (Colombia, Guatemala, Honduras, and Nicaragua) and Southeast Asia (Cambodia, Laos, Vietnam, and Philippines). Currently, there are $36 \mathrm{CSV}$ sites across the CCAFS's focal regions (Fig. 4).

The global representativeness of the CSV site network is evaluated using a climate analog tool (Ramirez-Villegas et al. 2011). The similarity between the monthly climates of each CSV with those of all other pixels with the same production system was computed using WorldClim data of precipitation and temperature (Hijmans et al. 2005). We give equal weight to each parameter and account hemispheric differences (Jones and Thornton 2000). Although temperature and precipitation are not the only climatic drivers, they do explain much of the variation in agricultural production worldwide (Ray et al. 2015). We then assessed how globally representative the entire set of sites was - each of the 36 CSV sites encompasses between three to seven localities for a total of $(n=$ 249) - by taking the maximum similarity value across all CSVs for each pixel (Fig. 5).

A substantial part of the global tropics and subtropics are highly representative, especially across the Sahel and South and Southeast Asia (Fig. 5). An area of ca. 2 million ha has $80 \%$ similarity for crops and pastures with ca. 4 and 5 million ha having $60 \%$ similarity. The tropical South America sites represent few other areas. Popayan (Colombia) represents only a limited amount of the highly diverse agricultural landscapes of the Andes or of Brazilian agricultural areas. In contrast, the CSVs of Central America, which are lower and drier, are more broadly representative.

Climate change is likely to alter the CSVs' climates, thus potentially altering their global representativeness. Therefore, representativeness of current CSV sites under future (2030s) climates was also analyzed using bias-corrected climate change projections from the Coupled Model Intercomparison Project Phase 5 (CMIP5) ensemble (Taylor et al. 2012) data for 33 general circulation models for the representative concentrations pathway 8.5. Results showed that, by the 2030s, similarities change only slightly, with most areas remaining within $\pm 5 \%$ of historical representativeness. Therefore, changes by the 2030s are not expected to alter the global representation of the CSV network. Thus, it is clear that the current CSV sites represent a large agricultural area of the world facing diverse climatic risks, and these sites will remain crucial for adaptation learning even in the future.

The CSV approach followed in Asia, Africa, and Latin America is very similar but highly contextualized in local situations. The 
Fig. 4. Climate-smart village sites located in 20 countries. These sites are typically in areas that have been identified as climate change "hotspots."

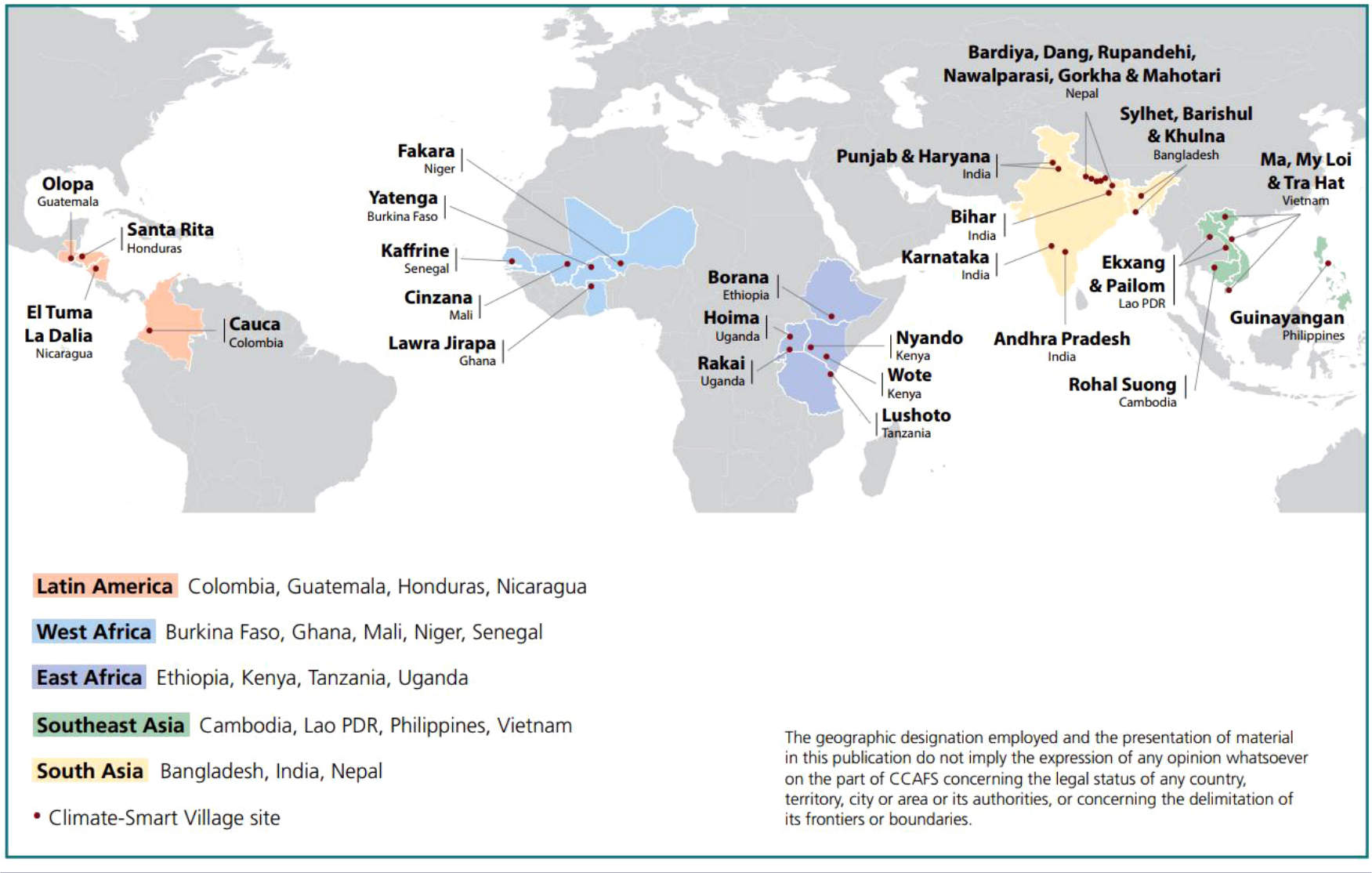

following section provides brief details of the approach used in different regions.

\section{The CSV approach in South Asia}

The CSV sites in South Asia are located in Punjab-Haryana, Bihar, Andhra Pradesh, and Karnataka states in India, six districts in Nepal (Rupandehi, Mahotari, Nawalparasi, Dang, Bardiya, and Gorkha) and in Barisal, Sylhet, and Khulna divisions of southern Bangladesh. The CSV approach in South Asia is described for the Punjab-Haryana sites.

Baseline: The region, important for the food security of all countries in South Asia, is dominated by rice-wheat systems. The key climatic risks are variable rainfall, increasing frequency of hailstorms, postharvest rains, and high temperatures especially during wheat grain-filling. Widespread use of diesel pumps for irrigation, especially for paddies, high use of inorganic fertilizers, residue burning are resulting in high GHG emissions in these CSV sites. Additional challenges are declining soil fertility and organic matter, monocropping, and depletion of the water table (Singh 2013, Centre for Environmental and Agricultural Policy Research, Extension and Development 2013, Bangladesh Centre for Advanced Studies 2013). Land is scarce, meaning that the potential for expanding the farmed area is very limited. Climate change will further exacerbate pressures on land and water resources.
CSV design: A multistakeholder platform of CGIAR centers, national agriculture research system (NARS), private sector, and farmer groups proposed a range of technologies, practices, and services. The interventions were aimed at increasing farm yield, income, input use efficiency (water, nutrients, and energy) and reducing GHG emissions. The options were prioritized by either (a) choice experiments with farmers and local governments (Taneja et al. 2014) or (b) the climate-smart adaptation prioritization toolkit (Shirsath et al. 2016). The selected interventions included crop diversification, conservation agriculture (minimum tillage, residue retention, laser leveling), improved varieties, weather-based insurance, and agroadvisory services, precision agriculture (leaf color charts, sensor-based nutrient/irrigation delivery systems) and agroforestry. Farmers' cooperatives were set up for custom hiring farm machinery, securing government credit for inputs, and sharing of experiences and knowledge.

Creating evidence: The short-listed options were trialled at the CSV sites to quantify trade-offs and synergies. The results showed that tillage practices and residue incorporation increased ricewheat yields by $5-37 \%$ and income by $28-40 \%$ and reduced $\mathrm{GHG}$ emission by $16-25 \%$ (Singh et al. 2009, Jat et al. 2014). Zero till with nutrient management increased crop yields by $11-58 \%$ and net income by $22-32 \%$ and reduced GHG emissions by $79-88 \%$ in the rice-wheat system (Aryal et al. 2014, Sapkota et al. 2014, 
Fig. 5. Global representativeness of the CSV network (blue dots). For each pixel, the value reported corresponds to the maximum similarity between the pixel's climate and all the climate-smart villages.

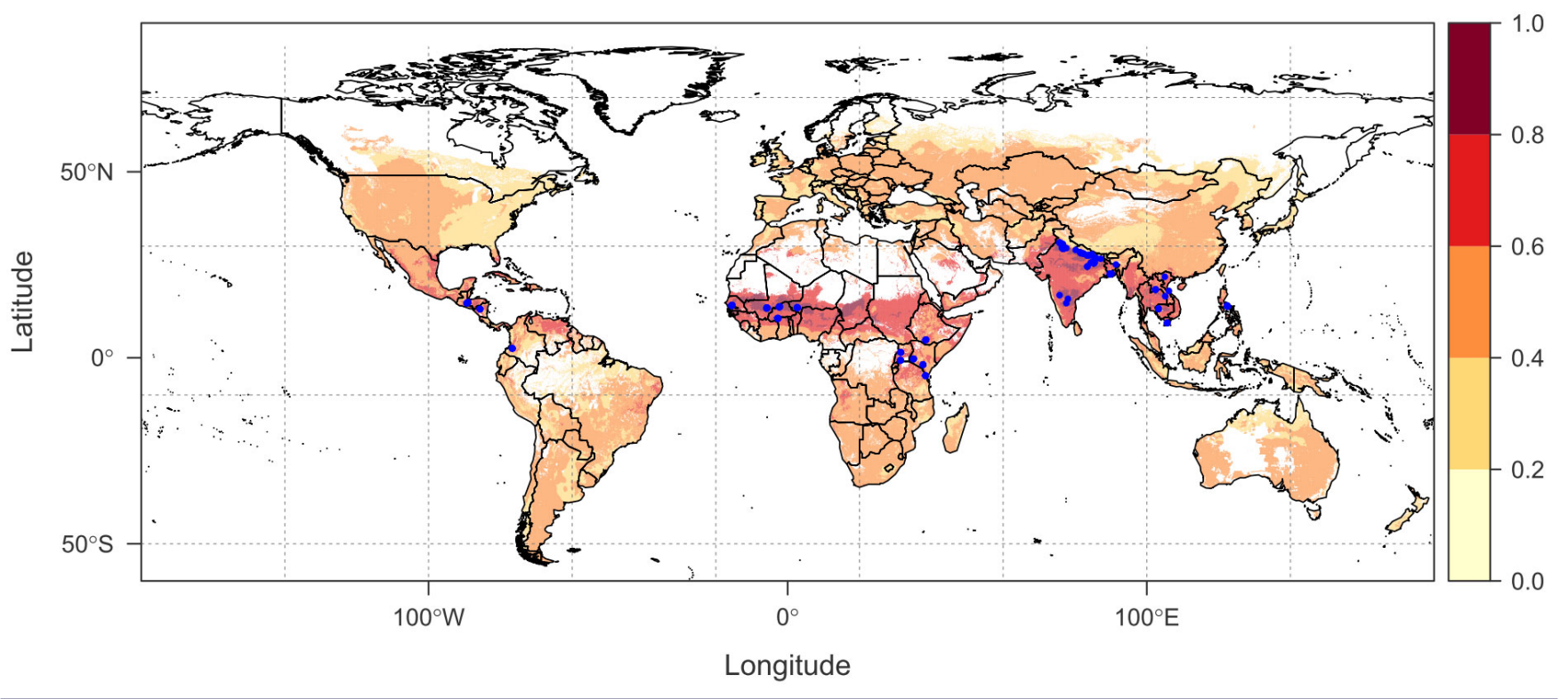

Khatri-Chhetri et al. 2016). These interventions also helped in avoiding burning of rice straw, which is very common in the CSV sites. Minimum tillage with direct seeded rice increased crop yields by $30-35 \%$ and net income by $7-34 \%$ and reduced $\mathrm{GHG}$ emissions by $9-38 \%$ (Jat et al. 2014). Water-use efficiency also increased by $30 \%$. Laser land leveling technology, which helps improve water and nutrient use efficiency, has increased crop yield by more than 7\% (Aryal at al. 2015).

The portfolio of CSA practices and technologies demonstrated multiplier effects on crop yields, nutrient use efficiency, and emissions reduction. The benefit of weather-based agroadvisories and insurance in combination with technology options in irrigated conditions of Haryana CSV remains unquantified. The portfolio of laser leveling, zero tillage, direct seeding rice, and precision nutrient management has been further evaluated by farmers in their own fields. Modeling is now being used intensively to assess the suitability of the portfolio of interventions in current and future climates (Shirsath et al. 2016).

Scaling out and up: The resultant portfolio of options proposed by CSV approach has been integrated with the agricultural development strategy of Haryana state, with the government now scaling out successful interventions to 500 other villages. These sites have become learning platforms for CSA in South Asia as well. State and even national governments have committed to scaling out the CSV approach to more than 2000 villages. In Nepal, the government has announced the implementation of CSVs to strengthen climate adaptation in the country's agriculture sector.

\section{The CSV approach in West Africa}

The AR4D CSV sites in West Africa are located in Cinzana (Mali), Fakara (Niger), Kaffrine (Senegal), Lawra-Jirapa (Ghana), and Yatenga (Burkina Faso). These sites were selected based on climate risk profiles, potential land-use options, and on willingness of farmers and local government to participate in the CSV process (Foerch et al. 2013). A detailed description of the CSV approach in the Kaffrine site is provided.

Baseline: Agriculture, which constitutes the main economic activity, is primarily rain fed and subsistence. Major staple crops are sorghum, millet, cowpea, and groundnut in Burkina Faso, Mali, Niger, and Senegal, whereas in Ghana, maize and yam are major crops. Intra- and interseasonal rainfall variability (Jalloh et al. 2013), declining soil fertility (Kamara et al. 2013), and land degradation are the major challenges for agriculture systems in much of West Africa. Specific climatic risks in Kaffrine CSV include droughts, floods, and winds. Poor harvests, postharvest losses due to pests and diseases, degradation of farmlands due to wind and water erosion, and decline in livestock production and availability of markets were identified as additional major constraints to agriculture.

CSV design: The Toolkit for Planning, Monitoring and Evaluation of Climate Change Adaptation (ToP-MECCA) was used to identify a list of suitable candidate interventions for each of the sites (Somda et al. 2011). In addition, mapping of local resources and climatic hazards and a gender-sensitive vulnerability analysis assisted in understanding the needs of different groups. The selected interventions for participatory testing included the use of climate information and services, water harvesting, microdosing of fertilizers, mulching, crop rotation, soil tillage, rangeland rehabilitation, community empowerment (demonstration farms, seed multiplication farms, exposure, and income generation activities), introduction of drought-tolerant seed/breeds, farmer-managed natural regeneration (FMNR), and planting suitable agroforestry tree species. Research and extension services, meteorological services, NGOs, private sector, local, regional, and international organizations, and community organizations were key players in the CSVs (Bayala et al. 2016). 
Creating evidence: The portfolios of interventions were evaluated in a research platform at the CSV site. Initial results in the Kaffrine CSV site showed that improved varieties of maize and millet led to an average $50 \%$ yield increase (compared with traditional varieties). In addition, combined soil tillage, fertilizer microdosing, and FMNR are potential sustainable intensification options that can improve farm incomes. It is expected that, as a cobenefit, better management of tree biomass could alleviate hazards such as strong winds, erosion, etc. while contributing to mitigation through carbon sequestration. Processing of nontimber forest products (NTFP) by women's groups, for example, generated a revenue of 171 euros per hectare. The use of climate information services by farmers resulted in reduced crop failure and increased by about $50 \%$ crop production (Lo and Dieng 2015). Household modeling has also been used to create improved evidence on interventions (Rigolot et al. 2015).

Scaling out and up: The CSVs across West Africa, and particularly in Kaffrine, have become learning grounds for policy makers and other stakeholders who use emerging evidence and lessons to develop and implement development plans. Farmers' field days, exchange visits, and local "durbars" and study tours have been conducted. Mobile phones, newspapers, and local radios have also been used for information dissemination. In Senegal, the national science-policy dialog platform has also been a useful framework for sensitization through which research results and experiences from the CSV sites are regularly shared by scientists and used to demonstrate effectiveness of diverse CSA technologies. Some evidence from the CSVs has also been used to mainstream CSA into major agricultural development programs (e.g., the Accelerated Program for Agriculture in Senegal).

\section{The CSV approach in East Africa}

In East Africa, the AR4D CSV sites are located in Kenya (Nyando and Makueni), Ethiopia (Borana), Tanzania (Lushoto), and Uganda (Hoima, Rakai). All sites are mixed crop-livestock production systems, except Borana site in Ethiopia, which mainly includes pastoral land.

Baseline: In East Africa CSVs, agricultural production is also subsistence and rainfed, with cropping systems dominated by maize, bananas, and beans. Livestock mostly comprises cattle, small ruminants (goats and sheep), and chicken. Rainfall variability is manifested by late onset or early cessation, and prolonged dry seasons that have become more frequent and intense (Recha et al. 2016). Incidences of diseases and pests are also increasing, affecting crops and livestock production. In addition, poverty, lost labor, and less diversified livelihoods make these communities more vulnerable to climate-related risks, with direct impacts on household food security and nutritional status.

CSV design: In the East Africa CSV sites, the prioritized interventions included weather information delivery services, water harvesting and soil conservation techniques, rangeland rehabilitation, community empowerment innovation (demonstration farms, seed multiplication farms, and village savings-and-loan schemes), introduction of drought-tolerant, short-duration, and disease-resistant crop varieties, and plantation of suitable agroforestry tree species. Livestock interventions included new resilient and improved breeds of small ruminant breeds and feeding strategies (Ojango et al. 2015, 2016).
Creating evidence: Early results show a shift to on-farm diversification, with households now adopting more than three crop innovations, greatly expanding on-farm choices for resilient varieties (Recha et al. 2015). Dual-purpose crops, such as sweet potatoes for food (tubers) and livestock feed (vines), are becoming more popular. The new livestock breeds have led to about onethird of the small ruminants in Nyando to be cross-breeds that are able to withstand heat stress, better utilize low quality forage, cope with disease burden, and recover from drought with faster compensatory growth, therefore maturing to market weight within a shorter period compared with the local breeds (Gilbert 2015, Ojango et al. 2016).

Scaling out and up: Scaling-out activities were mainly focused on farmer-to-farmer learning of climate-smart interventions through farmers' field days and exchange visits. These activities are supported by a range of extension service activities from the Ministry of Agriculture and Livestock and NGOs. Mobile phones for seasonal weather forecast information, newspapers, and local radios were also used for information dissemination to a large number of farmers.

\section{The CSV approach in Southeast Asia}

The CSV sites in Southeast Asia are located in Vietnam (Tra Hat, Ma, and My Loi), Lao PDR (Ekxang and Pailom), Cambodia (Rohal Suong), and the Philippines (Guiniyangan). They represent diverse climatic risks, landforms, cropping systems, and livelihood strategies. Sites range from small villages to larger geographic regions (Ma, My Loi, Guiniyangan). The main climate change issues addressed are sea-level rise, climate variability, and mitigating GHGs from rice production systems. The following sections focus on the sites in Vietnam.

Baseline: The sites in north and central Vietnam are hilly with agroforestry landscapes. Trees of Acacia and Eucalyptus spp. dominate, with agriculture covering only $10-20 \%$ of the area. Unusual cold and hot spells, typhoons, and prolonged droughts are common. Livelihoods rely on a single rice crop during the rainy season and livestock. The site in South Vietnam in the Mekong River delta is flat with low elevation. With water from the river and fertile alluvial soil, more than $80 \%$ of land grows two to three successive rice crops each year. The major problem is tidal salinity intrusion caused by low upstream water flow, whereas crops are disrupted by seasonal floods or occasional droughts.

CSV design: The Vietnam sites emphasize community-based responses to climate change adaptation. The local communities developed their strategy and action plan and implemented it through collective action to cope with climate change and unfavorable weather conditions. They developed a communityled land-use plan aimed at enhancing farmers' income and resilience and then tested CSA technologies prioritized using either structured prioritization tools or selected by village leaders and farmers in focus-group discussions. The resultant community visions were harmonized with the existing national policy perspectives and long-term strategies of higher administrative levels (i.e., commune, district, and province). Each CSV's community organizer facilitated communication and coordinating activities. Different farming activities created their own selfmanagement groups within local government and existing social organizations of the village. 
Creating evidence: Although only initiated recently, community response has been enthusiastic in adopting crop diversification, community pond water management, composting/manure management, and improved livestock management. Farmers and local partners state that the CSV approach gives farmers better access to advanced technologies, permits their evaluation in local context, and through capacity strengthening, allows them to adapt to the changing climate.

Scaling out and up: The CSV approach can be integrated with existing development programs such as "new rural community" in Vietnam, "Samsang" in Laos, and "village-based community development" in Cambodia. The CCAFS is currently working with local governments to use the CSV approach to scale out CSA and inform decision making (Gonsalves et al. 2015, Cruz et al. 2016). The Department of Agriculture's "Adaptation and Mitigation in Agriculture" project is a model for establishing climate-resilient agricultural communities in ten regions in the Philippines. It was also adopted as part of the CSA strategy of Myanmar's Ministry of Agriculture, Livestock and Irrigation (refer to http://www4.unfccc.int/submissions/Lists/ OSPSubmissionUpload/53 84131082106487817781 Myanmar agriculture \%20SBSTA44.pdf).

\section{The CSV approach in Latin America}

Sites in Latin America are located in Guatemala (Olopa), Honduras (Santa Rita), Nicaragua (El Tuma la Dalia), and Colombia (Cauca). The sites are in climatically vulnerable zones where there is increasing soil erosion, desertification, erratic weather patterns, widespread water scarcity, and high levels of poverty. The region is characterized by agroecological diversity, the production of the staple crops of beans and maize, commercial crops such as coffee and cocoa, and some extensive livestock. There are important agroecological differences between Colombia and Central America. The Cauca site in Colombia is described here.

Baseline assessment: Households buy over $80 \%$ of the food they consume because the farmland is used to grow coffee and sugar cane (Paz and Ortega 2014b). But coffee is becoming less suitable due to temperature increases caused by climate change. Main climate risks include reduced rainfall, increasing frost intensity, and higher daytime temperatures. Only $14 \%$ of farmers received climate information on extreme events at the start of the rainy season at a regional level. There was little formal government presence (Paz and Ortega 2014a, c), with few links with other organizations apart from the National Coffee Federation, which provides basic technical support. In Colombia, there was important community empowerment facilitated through the "Juntas de Acción Comunal" (nonprofit civil, social, communitarian, and neighborship organizations that join forces to add effort and resources to work toward solving the major needs of the community (Decree 1930 of 1979, Legal Regime of Bogotá) and the women's cooperative, which catalyzed village development initiatives. Women were more likely than men to adopt CSA practices and to use climate information to plan agricultural and household activities. Both men and women perceived changes in climate as mainly related to drought and increased temperatures (Twyman et al. 2016).
CSV design: Community leaders agreed to formulate a development plan considering climate as a key variable with technical support from CCAFS and the Ecohabitats Foundation (a local strategic partner). The first step was to develop vulnerability analyses at the farm level identifying each farm's hotspots of vulnerability to winds, precipitation, and drought. These were aggregated to develop farm- and community-level adaptation plans that identified potential adaptation measures and prioritize them considering their effect on costs, income, and food security. The plan included: more detailed weather monitoring; rainwater harvesting; vegetable gardens; biodigesters; and improved bean varieties. Concurrently, the project addressed youth and gender issues to strengthen their empowerment. Local research and regional government institutions provided support, and CCAFS engaged with the national Ministries of Environment and Agriculture and the Presidency Office for Postconflict.

Creating evidence: Although the program is still new, the CSV model has already helped to strengthen the partnership between local communities and national agriculture research systems in adaptation planning and implementation. The CSV sites are becoming learning platforms for many stakeholders in relation to climate-smart interventions in agriculture. The site is a focus of comprehensive research on GHG emissions in agricultural systems. It also enables detailed modeling and accounting of GHG fluxes from different land-use options. Additionally, it helps to develop a cost-benefit analysis of the implemented measures to understand the economic benefit and the associated cobenefits, such as biodiversity and water conservation.

Scaling up and scaling out: The "Juntas de Acción Comunal" have enabled community cohesion, which has been strengthened by the Ministry of Agriculture and Rural Development's land titling process. The stakeholder platform has evolved within this environment and now includes local and regional government and other institutions. The platform supports implementing CSA technologies, consolidates a resilient community, and improves livelihoods. Youth and children are part of the process and recognize opportunities to improve the quality of life.

In addition, farmers share experiences and lessons learned through farmer-to-farmer learning and exchanges among communities. Engagement with youth occurs through training in communication and GIS, which links academic institutions at the community and municipal level to national policy. For example, the Secretariat of Agriculture of Popayan is in the process of including this methodology to formulate local adaptation plans as part of the municipal environmental education process. The Secretariat will also implement a pilot in the CSV and will strengthen the Environment Youth Network at the municipality level.

\section{SYNTHESIS ACROSS CLIMATE-SMART VILLAGES}

\section{Synergies and trade-offs across interventions}

The CSV approach integrates technologies and services that are suitable for the local conditions. It provides multiple gains for food security and adaptation and for mitigation where appropriate. Table 1 presents the diversity of CSV approaches in the five CCAFS regions. Baseline assessments across all five regions indicate climatic risk sites and socioeconomic conditions together with a lack of resource availability are key issues 
Table 1. Diversity in CSV AR4D approach used in various CCAFS regions

\begin{tabular}{|c|c|c|c|c|}
\hline Region & Baseline Assessment & CSV Design & Creating evidence & Scaling Out/Up strategy \\
\hline $\begin{array}{l}\text { West } \\
\text { Africa }\end{array}$ & $\begin{array}{l}\text { Climatic Risks: drought, heat stress, and } \\
\text { high rainfall variability } \\
\text { Agricultural systems: rainfed, crop-livestock } \\
\text { farming systems, subsistence agriculture } \\
\text { Key agricultural constraints: capital, labor, } \\
\text { soil fertility, production inputs }\end{array}$ & $\begin{array}{l}\text { Scale: village community } \\
\text { Technology portfolio design: participatory } \\
\text { research methods } \\
\text { Climate information services: weather } \\
\text { forecasts, agro-advisories } \\
\text { Key technologies being implemented: }\end{array}$ & $\begin{array}{l}\text { On-farm research } \\
\text { platform } \\
\text { Participatory } \\
\text { evaluation by } \\
\text { stakeholders }\end{array}$ & $\begin{array}{l}\text { Participatory extension } \\
\text { services, science-policy } \\
\text { platform } \\
\text { Finance: community funds, } \\
\text { donor agencies, government }\end{array}$ \\
\hline
\end{tabular}

East Climatic risks: drought, extreme weather Africa events, dry spells Agricultural systems: rainfed, maize/ sorghum/livestock-based system, subsistence agriculture

Key agricultural constraints capital, labor, soil erosion, limited access

South Climatic risks: extreme weather events,

Asia rainfall variability, glacier melting, heat stress

Agricultural systems: largely irrigated, ricewheat systems, intensive agriculture, residue burning

Key agricultural constraints labor, energy, land degradation, over-pumping, high GHG emissions Asia excess rainfall Agricultural systems: irrigated, rice-based systems, horticulture/aquaculture/livestock Key agricultural constraints capital, labor constraints, soil degradation, high GHG emissions
Southeast Climatic risks: high rainfall variability,

agroforestry, soil and water conservation, improved crop varieties, poultry

husbandry

Scale: community

Technology portfolio design: participatory research methods

Climate information services: weather forecasts, agro-advisories, market integration

Key technologies being implemented: improved small ruminants, agroforestry, water management

Scale: village

Technology portfolio design: participatory research methods and modeling

Climate information services: weather forecasts, agro-advisories, crop insurance Key technologies being implemented: conservation agriculture, improved

varieties, crop diversification, solar irrigation

Scale: small landscape

Technology portfolio design: participatory research methods and modeling

Climate information services: weather forecasts, agro-advisories, knowledge enhancement services

Key technologies being implemented: cold, drought and saline-tolerant varieties of crops, water management, agroforestry, crop diversification, integrated crop management, crop residue management

Latin Climatic risks: high rainfall variability, heat America stress

Agricultural systems: partially irrigated, coffee-based systems

Key agricultural constraints: Capital, labor, land degradation, habitat loss, high GHG emissions
Scale: small landscapes research methods

Climate information services: weather

forecasts, agro-advisories

Key technologies being implemented:

rainwater harvesting and storage,

improved crop varieties
Technology portfolio design: participatory
On-farm research Participatory extension platform Participatory evaluation by stakeholders services, value-chain linkage

Finance: community innovation funds, donor agencies, private partnerships

On-farm research platform Participatory evaluation by stakeholders; large pilots

On-farm research Participatory extension platform Participatory evaluation by stakeholders services, policy linkage

Finance: community funds, donor agencies, private sector, government

On-farm research Participatory extension platform Participatory evaluation by stakeholders services, value-chain linkage, engagement with NGOs

Finance: community funds, donor agencies, private sector, government constraining agriculture. Access to resources is identified specifically in Africa, where poor market penetration renders farmers unable to procure inputs. The different agricultural systems dominant in each region shape the CSV design and key interventions, from rice-based systems in Southeast Asia, mixed crop-livestock systems in Africa, to coffee-based systems in Latin America. Low resource use and subsistence agriculture in Africa give low agricultural yields, whereas excessive resource use in South Asia (Punjab/Haryana, India) results in ecosystem degradation and environmental concerns.
As can be expected from the baseline assessments, technological interventions being piloted in CSV regions are very different. The portfolio of options in the South Asia CSVs had synergistic effects (Jat et al. 2014, Khatri-Chetri et al. 2016). Similarly, studies in all regions showed that there is considerable yield advantage when a portfolio of technologies is used, rather than technologies being used in isolation (Govaerts et al. 2005, Zougmore et al. 2014). For example, crop rotation with legumes, incorporation of crop residues and compost with minimum tillage enhances soil nutrients and ameliorates water stress through improved soil 
water relations. Crop varieties tolerant of stress, pests, and diseases, better timing and methods of crop establishment, and need-based water and nutrient applications are also promising. The CSVs provide the means by which farmers can explore these synergies. Improvement in soil properties and concomitant yield benefits due to CSA technologies take a long time (Gathala et al. 2011). The emphasis in CSVs is not on rediscovering or further testing them, but rather on evaluating and demonstrating their synergies with services such as weather forecast-based agroadvisories, crop insurance, and ICT-based knowledge and market management in current as well as future climate scenarios, and in bringing a climate lens to their evaluation to understand how well they deliver on resilience and mitigation.

The literature warns about the dangers of implementing blanket adaptation strategies without careful consideration of their potential disadvantages (Magnan et al. 2016). For example, conservation agriculture can be precarious for some smallholders, because it does not work in all agroecological settings. In some cases, the benefits can only be realized by adopting them together with other technologies (Pittelkow et al. 2014, Brouder and Gomez-Macpherson 2014). Unintended negative consequences can undermine CSV efforts if agronomic trials cannot be evaluated in diverse agroecologies and climate scenarios. This remains a serious challenge. The CSVs address this issue by indepth analysis of each technology in present climates and also assess their effectiveness in rapidly changing future socioeconomic scenarios (Vervoort et al. 2014). Modeling is therefore a very important tool in CSVs for supplementing technology evaluation done in on-farm research platforms. It is also essential to simulate the likely performance of technologies in future climates and to identify early any potential maladaptation. Such work is in progress (Shirsath et al. 2016).

\section{Synergies across scale: from local evaluation to global policy needs}

The primary unit of CSVs is generally the local administrative unit it belongs to, which makes it easier for uptake and to replicate elsewhere. South Asia and Africa sites used a "village" as the primary unit because scaling up and out was linked with the local and national government boundaries. This avoided the complex ownership, management, and financial issues that arise when using ecological units.

In Latin America and Southeast Asia, however, the approach was applied at a landscape level as the agricultural systems are highly diverse, and communities considered that they depend heavily on resources outside the village (e.g., through ecosystem services). In Latin America, social dynamics are important in adoption of new technologies, which are codeveloped and validated by local farmers. Involving the central government has not always worked, so livelihood improvement has often originated from bottom-up self-empowerment. Therefore, CCAFS has chosen a diversity of scales to bound CSVs that focus on local concerns, thus increasing chances of achieving impact.

A major objective of the CSV approach is scaling out local adaptation plans into existing policy space using strategies that are appropriate to the region concerned. In South Asia, the focus was on large-scale piloting for uptake and policy linkage. In Latin America and Africa, the focus was on value-chain linkage, science-policy platforms, and scaling out to participatory extension services. The diverse objectives of multiple stakeholders have always been included, but overall, poverty in developing countries is what forces farmers to maximize their incomes. In contrast, national policy makers focus on poverty alleviation as well as food security.

National and international agencies are often interested in GHG mitigation from agriculture. Modeling can aggregate data from field trials and extrapolate them to homogenous agroecological regions, which can make CSVs a useful approach for a variety of stakeholders. Modeling can also be used to understand their effectiveness in future climate scenarios.

Results from the different regions show that multistakeholder platforms and policy-making networks are key to effective upscaling. The effectiveness is increased when paired with capacity enhancement, learning, and innovative approaches to support farmers' decision making (Westermann et al. 2015). Challenges remain to promote uptake in the realities of local farming. Nevertheless, CSVs are a highly effective mechanism for bringing climate-smart options to scale and for forging links from the local level to national policy processes.

\section{CONCLUSION AND WAY FORWARD}

Climate-smart agriculture has shown promise at the local scale, but it has still not reached scale in most countries. This could be due to several barriers. For example, agriculture is not always the main priority at the local level, where there may be other priorities such as sanitation, health, or education. Adaptation to climate change may involve nonagricultural strategies such as migration, outside employment, and diversification from agriculture. The latter is already occurring in the population-rich and resourcescarce countries of South Asia. Poor infrastructure related to agriculture, including technologies, services, inputs, and access to markets, is a major issue in subsistence agricultural systems of Africa. There is also little capital available for investment in agriculture, which limits development of adaptation options such as demand-based climate information services and crop insurance. Another key constraint could be that CSA technologies are not well targeted because trade-offs among interventions are not well understood. There is often a mismatch and lack of dialog between science and policy needs in general and specifically about CSA.

Although many of these are generic barriers that prevent agriculture development, they are particularly relevant to CSVs, which are dependent on knowledge products. We trust, nevertheless, that the CSV approach is a step further to overcome some of these challenges by being more integrative and inclusive. As we have demonstrated earlier (Fig. 4), the current CSV sites represent a large agricultural area of the world facing diverse climatic risks, and these sites will remain crucial for adaptation learning even in the future. In India and Nepal, CCAFS partners have adopted the CSV approach and have expanded the number to thousands of CSVs, where results of CCAFS's AR4D approach are applied (Aggarwal et al., unpublished manuscript).

There is still a need for greater evidence for the CSV approach in different agroecological environments. It is especially important to understand the trade-offs between food security, adaptation, and mitigation in current and future socioeconomic and climate scenarios. More research is needed to demonstrate that 
adaptation strategies do not become maladaptive. The role of an appropriate monitoring and evaluation framework and indicators of climate smartness that can be easily measured becomes very important.

It is important that agriculture in developing countries should be resilient to climatic risks as well as increase production to meet increasing food demands. This paper has presented a scalable approach that integrates agronomic interventions, climate information services, and farmers' traditional knowledge at local scales. The components contribute to both resilience and mitigation. The CSV approach can be scaled out horizontally and locally through farmer participatory processes and farmer-tofarmer communication. With appropriate institutional support, a CSA portfolio can be scaled out to large numbers of farmers and thus address national food security, adaptation, and mitigation goals. The CSV approach also brings science into farming practice and combines development goals with actionbased research. The CSV is an "eco-regional" approach (Rabbinge 1995) that links bottom-up farming system research with environmental issues, livelihoods, and socioeconomics and connects knowledge generation to policy processes. It is unique in the sense that it provides an AR4D platform for multistakeholder participatory evaluation of CSA options and links global and local knowledge with local and national policies, thus presenting a holistic vision for sustainable agricultural development as well as confronting climate change action in agriculture. Although evidence for this is still being accumulated, the monitoring and evaluation framework linked to the baselines already collected will establish this in future years.

Responses to this article can be read online at: http://www.ecologyandsociety.org/issues/responses. php/9844

\section{Acknowledgments:}

We acknowledge the CGIAR Fund Council, Australia (ACIAR), International Fund for Agricultural Development (IFAD), Netherlands, Switzerland, and UK for funding to the CGIAR Research Program on Climate Change, Agriculture and Food Security (CCAFS). Authors thanks all CGIAR centers, national and local partners, and private sector participants in CCAFS regions for their support in field research and scaling out the CSV approach in the climatic risk-prone locations. The views expressed in the paper are the authors' alone.

\section{LITERATURE CITED}

Aggarwal, P. K., R. Zougmoré, and J. Kinyangi. 2013. Climatesmart villages: a community approach to sustainable agricultural development. CGIAR Research Program on Climate Change, Agriculture and Food Security (CCAFS), Copenhagen, Denmark.

Alexandratos, N., and J. Bruinsma. 2012. World agriculture towards 2030/2050: the 2012 revision. ESA Working paper No. 12-03. FAO, Rome, Italy. [online] URL: http://www.fao.org/ docrep/016/ap106e/ap106e.pdf
Aryal, J. P., M. B. Mehrotra, M. L. Jat, and H. S. Sidhu. 2015. Impacts of laser land leveling in rice-wheat systems of the northwestern Indo-Gangetic plains of India. Food Security 7(3):725738. http://dx.doi.org/10.1007/s12571-015-0460-y

Aryal, J. P., T. B. Sapkota, M. L. Jat, and D. K. Bishnoi. 2014. On-farm economic and environmental impact of zero-tillage wheat: a case of north-west India. Experimental Agriculture 51 (1):1-16. http://dx.doi.org/10.1017/S001447971400012X

Asseng, S., F. Ewert, P. Martre, R. P. Rötter, D. B. Lobell, D. Cammarano, B. A. Kimball, M. J. Ottman, G. W. Wall, J. W. White, M. P. Reynolds, P. D. Alderman, P. V. V. Prasad, P. K. Aggarwal, J. Anothai, B. Basso, C. Biernath, A. J. Challinor, G. De Sanctis, J. Doltra, E. Fereres, M. Garcia-Vila, S. Gayler, G. Hoogenboom, L. A. Hunt, R. C. Izaurralde, M. Jabloun, C. D. Jones, K. C. Kersebaum, A.-K. Koehler, C. Müller, S. Naresh Kumar, C. Nendel, G. O'Leary, J. E. Olesen, T. Palosuo, E. Priesack, E. Eyshi Rezaei, A. C. Ruane, M. A. Semenov, I. Shcherbak, C. Stöckle, P. Stratonovitch, T. Streck, I. Supit, F. Tao, P. J. Thorburn, K. Waha, E. Wang, D. Wallach, J. Wolf, Z. Zhao, and Y. Zhu. 2015. Rising temperatures reduce global wheat production. Nature Climate Change 5:143-147. http://dx.doi. org/10.1038/nclimate 2470

Bangladesh Centre for Advanced Studies (BCAS). 2013. Summary of Baseline Household Survey Results: Bagerhat, Bangladesh. CGIAR Research Program on Climate Change, Agriculture and Food Security (CCAFS), Copenhagen, Denmark. [online] URL: https://ccafs.cgiar.org/publications/ summary-baseline-household-survey-results-bagerhat-bangladesh\#. WlVnxainHIU

Bayala, J., R. Zougmoré, C. Ky-Dembele, B.A. Bationo, S. Buah, D. Sanogo, J. Somda, A. Tougiani, K. Traoré, and A. Kalinganire. 2016. Towards developing scalable climate-smart village models: approach and lessons learnt from pilot research in West Africa. ICRAF Occasional Paper No. 25. World Agroforestry Centre, Nairobi, Kenya. [online] URL: http://www.worldagroforestry. org/downloads/Publications/PDFS/OP16051.pdf

Brouder, S. M., and H. Gomez-Macpherson. 2014. The impact of conservation agriculture on smallholder agricultural yields: a scoping review of the evidence. Agriculture, Ecosystems and Environment 187:11-12. http://dx.doi.org/10.1016/j.agee.2013.08.010

Campbell, B. M., P. Thornton, R. Zougmoré, P. van Asten, and P. Lipper. 2014. Sustainable intensification: what is its role in climate smart agriculture?. Current Opinion in Environmental Sustainability 8:39-43. http://dx.doi.org/10.1016/j.cosust.2014.07.002

Campbell, B. M., S. J. Vermeulen, P. K. Aggarwal, C. CornerDolloff, E. Girvetz, A. M. Loboguerrero, ... and E. Wollenberg. 2016. Reducing risks to food security from climate change. Global Food Security 11:34 43. http://dx.doi.org/10.1016/j.gfs.2016.06.002

Center for Environmental and Agricultural Policy Research, Extension and Development (CEAPRED). 2013. Summary of Baseline Household Survey Results: Rupandehi, Nepal. CGIAR Research Program on Climate Change, Agriculture and Food Security (CCAFS), Copenhagen, Denmark. [online] URL: https://ccafs.cgiar.org/publications/summary-baseline-householdsurvey-results-rupandehi-nepal\#.WIVos6inHIU 
Challinor, A. J., J. Watson, D. B. Lobell, S. M. Howden, D. R. Smith, and N. Chhetri. 2014. A meta-analysis of crop yield under climate change and adaptation. Nature Climate Change 4:287291. http://dx.doi.org/10.1038/nclimate2153

Corner-Dolloff, C., A. M. Loboguerrero, M. Lizarazo, A. Nowak, F. Howland, N. Andrieu, and A. Jarvis. 2015. Decisionsupport framework for targeting investment towards climatesmart agriculture practices and programs. InC. Field, J. Jouzel, and H. Le Treut, compilers. Our common future under climate change, international scientific conference, 7-10 July 2015, Paris, France. [online] URL: http://pool7.kermeet.com/C/ewe/ewex/ unesco/DOCS/CFCC abstractBook.pdf

Cruz, A. C., R. Navarro, and L. Tabing. 2016. Climate change reporting for rural broadcasters: engaging rural media for community mobilization on climate-smart agriculture in the Philippines. CCAFS Working Paper No. 177, CGIAR, Copenhagen, Denmark. [online] URL: https://cgspace.cgiar.org/ rest/bitstreams/78547/retrieve

Doss, C., and C. Kieran. 2013. Standards for collecting sexdisaggregated data for gender analysis: a guide for CGIAR researchers. CGIAR Consortium, Montpelier, France. [online] URL: http://www.pim.cgiar.org/files/2012/05/Standards-for-Collecting$\underline{\text { Sex-Disaggregated-Data-for-Gender-Analysis.pdf }}$

Foerch, W., K. Sijmons, I. Mutie, J. Kiplimo, L. Cramer, P. Kristjanson, P. Thornton, M. Radeny, A. Moussa, and G. Bhatta. 2013. Core sites in the CCAFS regions: East Africa, West Africa and South Asia, Version 3. CGIAR Research Program on Climate Change, Agriculture and Food Security (CCAFS), Copenhagen, Denmark. [online] URL: https://ccafs.cgiar.org/publications/ ccafs-site-portfolio-core-sites-ccafs-regions-east-africa-west-africaand-south-asia\#.WSVt0vmGOUk

Food and Agriculture Organization (FAO). 2015. The state of food insecurity in the world 2015. Strengthening the enabling environment for food security and nutrition. FAO, Rome, Italy. [online] URL: http://www.fao.org/3/a-i4030e.pdf

Gathala, M. K., J. K. Ladha, V. Kumar, Y. S. Saharawat, V. Kumar, P. K. Sharma, S. Sharma, and H. Pathak. 2011. Tillage and crop establishment affects sustainability of south Asian rice-wheat system. Agronomy Journal 103(4):961-971. http://dx.doi. org/10.2134/agronj2010.0394

Gilbert, N. 2015. Climate-adaptation effort cuts hunger in African villages. Nature News, Nature Publishing Group, 13 March 2015. http://dx.doi.org/10.1038/nature.2015.17112

Gonsalves, J., L. Sebastian, B. Joven, C. Amutan, and A. Lucerna. 2015. Climate-smart villages: key concepts. Hanoi, Vietnam. CGIAR Research Program on Climate Change, Agriculture and Food Security (CCAFS), Copenhagen, Denmark. [online] URL: https://ccafs.cgiar.org/publications/climate-smart-villages-key-concepts\#. Vm6i8hqLTJE

Govaerts, B., K. D. Sayre, and J. Deckers. 2005. Stable high yields with zero tillage and permanent bed planting? Field Crop Research 94(1):33-42. http://dx.doi.org/https://doi.org/10.1016/j.fcr.2004.11.003

Hijmans, R. J., S. E. Cameron, J. L. Parra, P. G. Jones, and A. Jarvis. 2005. Very high resolution interpolated climate surfaces for global land areas. International Journal of Climatology 2515:1965-1978. http://dx.doi.org/10.1002/joc.1276
Intergovernmental Panel on Climate Change (IPCC). 2014. Climate change 2014: synthesis report. Contribution of Working Groups I, II and III to the Fifth Assessment Report of the Intergovernmental Panel on Climate Change [Core Writing Team, R. K. Pachauri and L. A. Meyer, editors]. IPCC, Geneva, Switzerland.

Jalloh, A., G. C. Nelson, T. S. Thomas, R. Zougmore, and H. Roy-Macauley. 2013. West African agriculture and climate change: a comprehensive analysis. International Food Policy Research Institute, Washington, D.C., USA. [online] URL: http://www. ifpri.org/publication/west-african-agriculture-and-climate-changecomprehensive-analysis

Jat, R. K., T. B. Sapkota, R. G. Singh, M. L. Jat, M. Kumar, and R. K. Gupta. 2014. Seven years of conservation agriculture in a rice-wheat rotation of eastern Gangetic Plains of South Asia: yield trends and economic profitability. Field Crops Research 164:199-210. http://dx.doi.org/10.1016/j.fcr.2014.04.015

Jones, P. G., and K. Thornton. 2000. MarkSim: software to generate daily weather data for Latin America and Africa. Agronomy Journal 923(3):445-453. http://dx.doi.org/10.2134/ agronj2000.923445x

Kamara A. Y., S. U. Ewansiha, and A. Menkir. 2013. Assessment of nitrogen uptake and utilization in drought-tolerant and Strigaresistant tropical maize varieties. Archives of Agronomy and Soil Science 60(2):195-207. http://dx.doi.org/https://doi. org/10.1080/03650340.2013.783204

Khatri-Chhetri, A., P. K. Aggarwal, P. K. Joshi, and S. Vyas. 2017. Farmers' prioritization of climate-smart agriculture CSA technologies. Agricultural Systems 151:184-191. http://dx.doi. org/10.1016/j.agsy.2016.10.005

Khatri-Chhetri, A., J. P. Aryal, T. B. Sapkota, and R. Khurana. 2016. Economic benefits of climate-smart agricultural practices to smallholder farmers in the Indo-Gangetic Plains of India. Current Science 110(7):1251-1256.

Lipper, L., P. Thornton, B. M. Campbell, T. Baedeker, A. Braimoh, M. Bwalya, P. Caron, A. Cattaneo, D. Garrity, K. Henry, R. Hottle, L. Jackson, A. Jarvis, F. Kossam, W. Mann, N. McCarthy, A. Meybeck, H. Neufeldt, T. Remington, Pham Thi Sen, R. Sessa, R. Shula, A. Tibu, and E. F. Torquebiau. 2014. Climate-smart agriculture for food security. Nature Climate Change 4(12):1068-1072. http://dx.doi.org/10.1038/nclimate2437

Lo, H.M., and M. Dieng. 2015. Impact assessment of communicating seasonal climate forecasts in Kaffrine, Diourbel, Louga, Thies and Fatick niakhar regions in Senegal. CGIAR Research Program on Climate Change, Agriculture and Food Security (CCAFS), Copenhagen, Denmark. [online] URL: http:// bit.ly/1ifHC3P

Lobell, D. B., A. Sibley, and J. I. Ortiz-Monasterio. 2012. Extreme heat effects on wheat senescence in India. Nature Climate Change 2(3):186-189. http://dx.doi.org/10.1038/nclimate1356

Magnan, A. K., E. L. F. Schipper, M. Burkett, S. Bharwani, I. Burton, S. Eriksen, F. Gemenne, L. Schaar, and G. Ziervogel. 2016. Addressing the risk of maladaptation to climate change. Wiley Interdisciplinary Reviews: Climate Change 7(5):646-665. http://dx.doi.org/10.1002/wcc.409 
Millenium Villages Project. 2016. Webpage. [online] URL: http:// millenniumvillages.org/the-villages/

Ojango, J.M., J.O. Audho, E. Oyieng, J. Recha, and A. Muigai. 2015. Sustainable small ruminant breeding program for climate smart villages in Kenya. CCAFS Working Paper no. 127. CGIAR Research Program on Climate Change, Agriculture and Food Security CCAFS, Copenhagen, Denmark. [online] URL: https:// ccafs.cgiar.org/publications/sustainable-small-ruminant-breedingprogram-climate-smart-villages-kenya\#.WSV83fmGOUk

Ojango, J. M. K., J. Audho, E. Oyieng, J. Recha, A. M. Okeyo, J. Kinyangi, and A. W. T. Muigai. 2016. System characteristics and management practices for small ruminant production in "climatesmart villages" of Kenya. Animal Genetic Resources/Ressources génétiques animales/Recursos genéticos animales 58:101-110. http://dx.doi.org/10.1017/S2078633615000417

Palanisami, K., D. S. Kumar, R. P. S. Malik, S. Raman, G. Kar, and K. Monhan. 2015. Managing water management research: analysis of four decades of research and outreach programmes in India. Economic and Political Weekly I(26/27):33-43.

Paz, L., and L. Ortega. 2014a. CCAFS Community baseline report for Cauca, Colombia CSV. CGIAR Research Program on Climate Change, Agriculture and Food Security (CCAFS), Copenhagen, Denmark. [online] URL: https://cgspace.cgiar.org/handle/10568/80199

Paz, L., and L. Ortega. 2014b. CCAFS household baseline report for Cauca, Colombia CSV. CGIAR Research Program on Climate Change, Agriculture and Food Security (CCAFS), Copenhagen, Denmark. [online] URL: https://cgspace.cgiar.org/handle/10568/77728

Paz, L. and Ortega, L. 2014c. CCAFS Organization baseline report for Cauca, Colombia CSV. CGIAR Research Program on Climate Change, Agriculture and Food Security CCAFS. [online] URL: https://cgspace.cgiar.org/handle/10568/80486

Perez, C., E. M. Jones, P. Kristjanson, L. Cramer. P. K. Thornton, W. Förch, and C. Barahona. 2015. How resilient are farming households and communities to a changing climate in Africa? A gender-based perspective. Global Environmental Change 34:95107. http://dx.doi.org/10.1016/j.gloenvcha.2015.06.003

Pittelkow, C. M., X. Liang, B. A. Linquist, K. J. van Groenigen, J. Lee, M. E. Lundy, N. van Gestel, J. Six, R. T. Venterea, and C. van Kessel. 2014. Productivity limits and potentials of the principles of conservation agriculture. Nature 517(7534):365368. http://dx.doi.org/10.1038/nature13809

Porter, J. R., L. Xie, A. J. Challinor, K. Cochrane, S. M. Howden, , M. M. Iqbal, D. B. Lobell, and M. I. Travasso. 2014. Food security and food production systems. Pages 485-533 in C. B. Field, V. R. Barros, D. J. Dokken, K. J. Mach, M. D. Mastrandrea, T. E. Bilir, M. Chatterjee, K. L. Ebi, Y. Otsuki Estrada, R. C. Genova, B. Girma, E. S. Kissel, A. N. Levy, S. MacCracken, P. R. Mastrandrea, and L. L. White, editors. Climate Change 2014: impacts, adaptation, and vulnerability. Part A: global and sectoral aspects. Contribution of Working Group II to the Fifth Assessment Report of the Intergovernmental Panel on Climate Change, Cambridge University Press, Cambridge, UK and New York, New York, USA.

Quisumbing, A.R., and L. Pandolfelli. 2010. Promising approaches to address the needs of poor female farmers:
Resources, constraints, and interventions. World Development 384:581-592. http://dx.doi.org/10.1016/j.worlddev.2009.10.006

Rabbinge, R. 1995. Eco-regional approaches, why, what and how. Pages 3-11 in J. Bouma, A. Kuyvenhoven, B. A.M. Bouman, J. C. Luyten, and H. G. Zandstra, editors. Eco-regional approaches for sustainable land use and food production. Proceedings of a symposium on eco-regional approaches in agricultural research, 12-16 December 1994, Springer, The Hague, The Netherlands. http://dx.doi.org/10.1007/978-94-011-0121-9 1

Ramirez-Villegas, J., C. Lau, A. K. Köhler, J. Signer, A. Jarvis, N. W. Arnell, T. M. Osborne, and J. Hooker. 2011. Climate analogues: finding tomorrow's agriculture today, Working paper No. 12. CGIAR Research Program on Climate Change, Agriculture and Food Security CCAFS, Cali, Colombia. [online] URL: http:// www.riesgoycambioclimatico.org/biblioteca/archivos/DC1144.pdf

Ray, D. K., J. S. Gerber, G. K. MacDonald, and P. C. West. 2015. Climate variation explains a third of global crop yield variability. Nature Communications 6: 5989. http://dx.doi.org/10.1038/ ncomms6989

Recha, J. W., B. M. Mati, M. Nyasimi, P. K. Kimeli, J. M. Kinyangi, and M. Radeny. 2016. Changing rainfall patterns and farmers' adaptation through soil water management practices in semi-arid eastern Kenya. Arid Land Research and Management 30(3):229-238. http://dx.doi.org/10.1080/15324982.2015.1091398

Recha, J., M. Radeny, J. Kinyangi, P. Kimeli, V. Atakos, C. Lyamchai, R. Ngatoluwa, and G. Sayula. 2015. Climate-smart villages and progress in achieving household food security in Lushoto, Tanzania. CCAFS Info Note. CGIAR Research Program on Climate Change, Agriculture and Food Security CCAFS, Copenhagen, Denmark. [online] URL: https://cgspace. cgiar.org/handle/10568/70257

Rigolot, C., I. Watson, M. Herrero, B. J. Delma, E. Vall, N. Andrieu, B. Yacouba, S. Ouédraogo, R. Ziebe, V. Dowe, T. Kolyang, D. Prestwidge, C. McDonald,R. Stirzaker, C. Bruce, and P. Carberry. 2015. Modelling households and value chains: complementary methods for learning and evaluation in innovations platforms. Pages 25-27 in Conférence internationale sur les systèmes d'innovation en Afrique de l'Ouest et du Centre. [online] URL: https://www.researchgate.net/profile/Cyrille Rigolot/ publication/281597212 Modelling households and value chains_Complementary methods for_learning and evaluation in innovations platforms/links/5671d95d08ae54b5e45fb003.pdf

Rosenzweig, C., J. Elliott, D. Deryng, A. C. Ruane, C. Müller, A. Arneth, ... J. W. Jones. 2014. Assessing agricultural risks of climate change in the 21 st century in a global gridded crop model intercomparison. Proceedings of the National Academy of Sciences of the United States of America 111(9):3268-3273. http:// dx.doi.org/https://doi.org/10.1073/pnas. 1222463110

Sapkota, T. B., K. Majumdar, M. L. Jat, K. Kumar, D. K. Bishnoi, A. J. McDonald, and M. Pampolino. 2014. Precision nutrient management in conservation agriculture based wheat production of Northwest India: profitability, nutrient use efficiency and environmental footprint. Field Crops Research 155:233-244. http://dx.doi.org/10.1016/j.fcr.2013.09.001 
Schellnhuber, H. J., K. Frieler, and P. Kabat. 2013. Global climate impacts: a cross-sector, multi-model assessment special feature introduction: the elephant, the blind, and the inter-sectoral intercomparison of climate impacts. Proceedings of the National Academy of Sciences of the United States of America 111(9):32253227. http://dx.doi.org/https://doi.org/10.1073/pnas.1321791111

Shirsath, P. B., P. K. Aggarwal, P. K. Thornton, and A. Dunnett. 2016. Prioritizing climate-smart agricultural land use options at a regional scale. Agricultural Systems 151:174-183. http://dx.doi. org/10.1016/j.agsy.2016.09.018

Singh R. K. P. 2013. Summary of baseline household survey results: Karnal, Haryana State, India. CGIAR Research Program on Climate Change, Agriculture and Food Security (CCAFS), Copenhagen, Denmark. [online] URL: https://ccafs.cgiar.org/ publications/summary-baseline-household-survey-results-karnalharayana-state-india\#.WlVpXKinHIU

Singh Y., E. Humphreys, S. S. Kukal, B. Singh, A. Kaur, S. Thaman, A. Prashar, S. Yadav, J. Timsina, S. S. Dhillon, N. Kaur, D. J. Smith, and P. R. Gajri. 2009. Crop performance in permanent raised bed rice-wheat cropping system in Punjab, India. Field Crops Research 110(1):1-20. http://dx.doi.org/10.1016/j.fcr.2008.06.009

Somda, J., A. Faye, and H. D. Ouaga. 2011. Handbook and user guide of the toolkit for planning, monitoring and evaluation of climate change adaptive capacities. Niamey, Niger. [online] URL: https://cmsdata.iucn.org/downloads/top secac agrhymet english. pdf

Steenwerth, K. L., A. K. Hodson, A. J. Bloom, M. R. Carter, A. Cattaneo, C. J. Chartres, J. L Hatfield, K. Henry, J. W. Hopmans, W. R. Horwath, B. M. Jenkins, E. Kebreab, R. Leemans, L. Lipper, M. N. Lubell, S. Msangi, R. Prabhu, M. P. Reynolds, S. Sandoval Solis, W. M. Sischo, M. Springborn, P. Tittonell, S. M. Wheeler, S. J. Vermeulen, E. K. Wollenberg, L. S. Jarvis, and L. E. Jackson. 2014. Climate-smart agriculture global research agenda: scientific basis for action. Agriculture and Food Security 3(1): 11. http://dx. doi.org/10.1186/2048-7010-3-11

Taneja, G., B. D. Pal, P. K. Joshi, P. K.Aggarwal, and N. K. Tyagi. 2014. Farmers preferences for climate-smart agriculture: an assessment in the Indo-Gangetic Plain. IFPRI Discussion Paper 1337. New Delhi, India. [online] URL: https://ccafs.cgiar.org/ publications/farmers-preferences-climate-agriculture-assessmentindo-gangetic-plain\#.WSZhT_mGOUk

Taylor, K. E., R. J. Stouffer, and G. A. Meehl. 2012. An overview of CMIP5 and the experiment design. Bulletin of the American Meteorological Society 93:485-498. http://dx.doi.org/10.1175/ BAMS-D-11-00094.1

Thornton, P. K., and M. Herrero. 2010. Potential for reduced methane and carbon dioxide emissions from livestock and pasture management in the tropics. Proceedings of the National Academy of Sciences 107(46):19667-19672. http://dx.doi.org/10.1073/ pnas.0912890107

Twyman, J., J. Muriel, and M. Clavijo. 2016. Gender survey report: Cauca, Colombia. CCAFS Report. CGIAR Research Program on Climate Change, Agriculture and Food Security CCAFS, Copenhagen, Denmark. [online] URL: https://ccafs.cgiar.org/es/ publications/reporte-encuesta-de-g $\%$ C3\%A9nero-cauca-colombia\#. WSZivPmGOUk

Vermeulen, S. J., B. M. Campbell, and J. S. Ingram. 2012. Climate change and food systems. Annual Review of Environment and Resources 37:195-222. http://dx.doi.org/10.1146/annurevenviron-020411-130608

Vervoort, J. M., P. Thornton, P. Kristjanson, W. Förch, P. J. Ericksen, K. Kok, J. S. I. Ingram, M. Herrero, A. Palazzo, A. E. S. Helfgott, A. Wilkinson, P. Havlik, D. Mason-D'Croz, and C. Jost. 2014. Challenges to scenario-guided adaptive action on food security under climate change. Global Environmental Change 28:383-394. http://dx.doi.org/10.1016/j.gloenvcha.2014.03.001

Westermann, O., W. Förch, and P. K. Thornton. 2015. Reaching more farmers: innovative approaches to scaling up climate smart agriculture.: CCAFS Working Paper no. 135. CGIAR Research Program on Climate Change, Agriculture and Food Security CCAFS, Copenhagen, Denmark. [online] URL: https://ccafs. cgiar.org/publications/reaching-more-farmers-innovative-approachesscaling-climate-smart-agriculture\#.WSZj vmGOUk

Zougmoré, R., A. Jalloh, and A. Tiore. 2014. Climate-smart soil, water and nutrient management options in semiarid West Africa: a review of evidence and analysis of stone bunds and zai techniques. Agriculture and Food Security 3(1): 16. http://dx.doi. org/10.1186/2048-7010-3-16 